\title{
Upaya Meningkatkan Hasil Belajar Lempar Lembing Melalui Gaya Mengajar Resiprokal Pada Siswa Kelas VIII A SMP Negeri 3 Nipah Panjang Kabupaten Tanjabtim Tahun Ajaran 2015/2016
}

\author{
Drs. Arsil, M.Pd \\ Correspondence: Fakultas Ilmu Keolahragaan Universitas Jambi, \\ Jambi, Indonesia \\ E-mail: Arsil.fkip@unja.ac.id
}

\begin{abstract}
Abstrak
Penelitian ini bertujuan untuk mengetahui seberapa besar peningkatan hasil belajar lempar lembing yang didapat siswa kelas VIII A SMP Negeri 3 Nipah Panjang Kabupaten Tanjabtim Tahun Ajaran 2015/2016 melalui gaya mengajar resiprokal. Subjek Penelitian ini dilaksanakan di SMP Negeri 3 Nipah Panjang Kabupaten Tanjabtim Tahun Ajaran 2015/2016, sampel dalam penelitian ini adalah siswa kelas VIII A yang berjumlah 27 orang. Metode penelitian yang digunakan adalah metode penelitian tindakan kelas. Untuk memperoleh data dalam penelitian ini maka dilakukan tes hasil belajar yang berbentuk portofolio, dan dilanjutkan dengan pembelajaran melalui penerapan gaya mengajar resiprokal. Berdasarkan hasil tes lempar lembing sebelum siklus yang dilakukan pada siswa kelas kelas VIII A SMP Negeri 3 Nipah Panjang Kabupaten Tanjabtim Tahun Ajaran 2015/2016. Dari 27 siswa terdapat 5 siswa (18,51\%) yang telah mencapai tingkat ketuntasan belajar dengan nilai rata-rata hasil belajar siswa 40,50. Hasil dari siklus I terdapat 16 siswa (59,25\%) dari 27 siswa, yang telah mencapai tingkat ketuntasan belajar dengan nilai rata-rata hasil belajar siswa 64,12. Di siklus II terdapat 23 siswa (85,18\%) dari 27 siswa yang telah mencapai tingkat ketuntasan belajar dengan nilai rata-rata 86,80. Dapat dikatakan melalui penerapan gaya resiprokal dapat meningkatkan hasil belajar siswa.
\end{abstract}

\section{Kata Kunci: Hasil Belajar, Lempar Lembing, Resiprokal}

\section{Pendahuluan}

Pendidikan jasmani merupakan suatu proses pembelajaran melalui aktivitas jasmani yang didesain untuk meningkatkan kebugaran jasmani, mengembangkan keterampilan motorik, pengetahuan dan perilaku hidup sehat dan aktif, sikap sportif, dan kecerdasan emosi. Lingkungan belajar diatur secara saksama untuk meningkatkan pertumbuhan dan perkembangan seluruh ranah, jasmani, psikomotor, kognitif, dan afektif setiap siswa, Samsudin (2008).

Pendidikan mempunyai peranan yang cukup besar dalam membina kehidupan bermasyarakat menuju masa depan yang lebih baik. Hal ini disebabkan karena pendidikan merupakan upaya untuk meningkatkan kualitas setiap individu baik secara langsung ataupun tidak langsung dipersiapkan untuk menopang dan mengikuti laju perkembangan ilmu pengetahuan dan teknologi dalam rangka mensukseskan pembangunan yang sejalan dengan kebutuhan manusia.

Perkembangan ilmu pengetahuan dan tekhnologi semakin mendorong upaya-upaya untuk pembaharuan dalam pemanfaatan hasil-hasil teknologi dalam proses belajar. Belajar suatu proses yang kompleks yang terjadi pada diri sendiri setiap orang sepanjang hidupnya. Proses belajar itu terjadi karena adanya interaksi antara seseorang dengan lingkungannya. Oleh karena itu, belajar dapat terjadi

PJKR_ 
kapan saja dan dimana saja. Salah satu pertanda bahwa seseorang itu telah belajar adanya perubahan tingkah laku pada diri orang itu yang tampak pada terjadinya perubahan pada tingkat pengetahuan, keterampilan dan sikapnya. Olahraga bagian dari kehidupan yang tidak terpisahkan dari semua aspek kehidupan manusia. Secara teori, jasmani dan rohani seorang dapat menjadi sehat apabila berolahraga yang teratur, terukur dan terprogram dengan baik. Kesehatan jasmani dan rohani ini sangatlah penting dalam menghadapi tantangan hidup sepanjang kehidupan manusia.

Terkait dengan pembelajaran pendidikan jasmani khususnya dinomor atletik lempar lembing merupakan pelajaran yang diberikan siswa SMP Negeri 3 Nipah Panjang Kabupaten Tanjabtim, khususnya di kelas VIII A. Standar Kriteria Ketuntasan Minimal (KKM) yang harus dicapai siswa adalah 70. Kenyataan menunjukan bahwa siswa kelas VIII A siswa masih banyak yang tidak mampu melampaui nilai sesuai KKM. Faktor yang sangat mempengaruhi hasil belajar siswa adalah, kurangnya minat pada siswa di sekolah tersebut hanya sebagian siswa yang minat dan kemauannya besar dan yang lainnya lebih senang melakukan hal yang diluar konteks pembelajaran pendidikan jasmani. Menyadari hal tersebut, perlu adanya suatu pembaharuan atau tindakan yang harus dilakukan khususnya pada guru olahraga di sekolah tersebut, dalam pembelajaran untuk memungkinkan meningkatkan hasil pembelajaran siswa dapat mempelajari pendidikan jasmani dan kesehatan khususnya materi lempar lembing menjadi lebih mudah, lebih cepat, lebih bermakna, efektif dan menyenangkan bagi siswa di sekolah tersebut.

Untuk itu diperlukan suatu cara agar siswa dapat menguasai gerakan lempar lembing dengan benar sehingga akan menghasilkan teknik lemparan yang benar dan maksimal. Jika selama ini guru pendidikan jasmani kesehatan menyajikan materi lempar lembing dengan menggunakan strategi pembelajaran yang membosankan tanpa mengikut sertakan siswa-siswa dalam proses pembelajaran yang berlangsung, maka disini guru menyajikan dan memberikan materi pelajaran dengan menggunakan metode dan strategi yang melibatkan seluruh siswa dalam proses belajar mengajar.

Berdasarkan observasi di SMP Negeri 3 Tanjabtim kelas VIII A tentang pelajaran lempar lembing, masih banyak di temukan siswa yang mengalami kesulitan pada teknik dasar lempar lembing, hal itu terbukti banyak siswa yang belum memahami bagaimana cara memegang lembing yang benar, sikap awal dan akhir siswa pada saat melempar lembing. Salah satu penyebab hal ini adalah karena kurang di terapkannya gaya pembelajaran yang lain, pada hal sudah banyak gaya mengajar yang di temukan. Proses pembelajaran penjas disekolah juga cenderung membosankan karena guru mempraktekkan dan siswa mengikuti tanpa melihat kebenaran teknik tersebut. Hal ini terbukti siswa lebih menyenangi pelajaran penjas. Hal tersebut di karenakan guru hanya memberikan materi dan membiarkan siswa bermain tanpa ada pengawasan dari guru pada jam pelajaran berlangsung. Untuk itu peneliti menggunakan gaya mengajar resiprokal, karena peneliti ingin melihat perkembangan kemampuan siswa dalam proses belajar lempar lembing. Gaya mengajar resiprokal bertujuan untuk melibatkan semua 
siswa, menyesuaikan terhadap perbedaan individu, memberi kesempatan untuk memulai tugas pada tingkat kemampuan sendiri, memberi kesempatan untuk menilai tugas dengan tugas-tugas yang lebih ringan dan dilanjutkan ke tingkat tugas yang lebih sulit (berjenjang) sesuai dengan tingkat kemampuan tiap siswa, belajar melihat hubungan antara kemampuan merasa dan tugas apa yang dapat dilakukan oleh siswa, individualisasi dimungkinkan karena memilih diantara alternatif tingkat tugas yang telah disediakan.

Alasan peneliti untuk menerapkan gaya mengajar resiprokal adalah agar para siswa tidak jenuh pada saat melaksakan pelajaran penjas dan para siswa mendapatkan nuansa baru dalam belajar penjas dengan melibatkan sesama temannya sebagai pelaku dan pelaksana, jadi adanya timbul suatu sikap atau tindakan pada siswa agar memacu kemampuan mereka masing - masing agar bisa melakukan lempar lembing dengan benar. Kenapa mereka ingin melakukannya dengan benar, karena mereka juga terlibat dan memberikan contoh yang benar dalam penelitian gaya mengajar resiprokal. Dengan gaya mengajar resiprokal ini bisa menjadi solusi peneliti agar meningkatkan hasil belajar siswa di SMP Negeri 3 Nipah Panjang Tanjabtim khususnya lempar lembing. Peneliti ingin melihat penerapan gaya mengajar resiprokal dapat meningkatkan hasil belajar lempar lembing siswa kelas VIII A. Proses yang dimaksud dalam belajar lempar lembing adalah mulai dari cara pegangan, cara melempar, sikap badan saat akan melempar dan sikap badan setelah melakukan melempar, agar para siswa dapat memenuhi KKM yang ditetapkan sekolah.

Berdasarkan uraian diatas, maka penulis tertarik melakukan suatu penelitian yang berjudul "Upaya Meningkatkan Hasil Belajar Lempar Lembing Melalui Gaya Mengajar Resiprokal Pada Siswa Kelas VIII A SMP Negeri 3 Nipah Panjang Kabupaten Tanjabtim”.

Tujuan dari penelitian ini adalah: "Untuk mengetahui seberapa besarkah peningkatan hasil belajar lempar lembing dengan melalui gaya mengajar resiprokal pada siswa kelas VIII A SMP Negeri 3 Nipah Panjang Kabupaten Tanjabtim".

Hasil belajar adalah sejumlah pengalaman yang diperoleh siswa yang mencakup ranah kognitif, afektif, dan psikomotorik. Belajar tidak hanya penguasaan konsep teori mata pelajaran saja, tapi juga penguasaan kebiasaan, persepsi, kesenangan, minat-bakat, penyesuaian sosial, ketermpilan, sita-sita, keinginan dan harapan, Propayanda (2014).

Menurut Hamalik (2008) menjelaskan bahwa hasil belajar adalah sebagai terjadinya perubahan tingkah laku pada diri seseorang yang dapat diamati dan diukur bentuk pengetahuan, sikap dan keterampilan. Perubahan tersebut dapat diartikan sebagai terjadinya peningkatan dan pengembangan yang lebih baik sebelumnya yang tidak tahu menjadi tahu.

Menurut Mulyasa (2008) menjelaskan hasil belajar adalah prestasi belajar siswa secara keseluruhan yang menjadi indikator kompetensi dan derajat perubahan perilaku yang berangkutan. Kompetensi yang harus dikuasai siswa perlu dinyatakan sedemikian rupa agar dapat dinilai sebagai wujud hasil belajar 
siswa yang mengacu pada pengalaman lansung. Dari uraian diatas dapat disimpulkan bahwa hasil belajar merupakan proses dimana kegiatan belajar yang mengacu pada tingkat keberhasilan, pemahaman tentang materi dan penguasaan materi pembelajaran tersebut.

Pada gaya resiprokal, kelas diorganisir dan dikondisikan dalam peranperan tertentu (dibagi menjadi dua kelompok), ada peserta didik/siswa yang berperan sebagai pelaku, dan sebagai observer (pengamat) terhadap aktivitas yang dilakukan oleh kelompok pelaku, sedangkan guru sebagai fasilitator.

Kelompok siswa yang bertindak sebagai observer mengamati tampilan/aktivitas yang dilakukan oleh temannya (pelaku) dengan membawa lembar observasi (pengamatan) yang telah disusun oleh guru, selanjutnya observer tersebut mengevaluasi tampilan dari kawannya yang bertindak sebagai pelaku. Dalam hal ini evaluasi dilakukan oleh peserta didik/siswa sendiri secara bergantian. Melalui upaya mengevaluasi aktivitas temannya, diharapkan siswa juga mengetahui konsep pelaksanaan yang benar, karena setiap siswa akan berperan sebagai observer (pengamat), maka mereka akan berupaya untuk menguasai konsep geraknya yang benar. Tanggung jawab dan pemberian umpan balik diberikan kepada siswa. Untuk pelaksanaan gaya resiprokal, siswa terlebih dahulu harus mempelajari teknik dasar, dan gaya resiprokal ini dilaksanakan pada pembelajaran teknik lanjutan.

Menurut Mahendra (2000) pengambilan keputusan secara skematis dalam gaya berbalasan ( reciprocal style ) terlihat seperti dibawah ini :

Tabel 1. Pengambilan Keputusan Skematis Gaya Mengajar Resiprokal

\begin{tabular}{cccc}
\hline & A & B & C \\
\hline Pre Impact & Guru & Guru & Guru \\
\hline Impact & Guru & Murid & Pelaku \\
\hline Post Impact & Guru & Guru & Pengamat
\end{tabular}

Adapun langkah - langkah gaya mengajar resiprokal yang dimulai dari penyampaian tujuan, memotivasi hingga memberi penghargaan terhadap siswa atau kelompok dapat dilihat sebagai berikut :

Tabel 2. Langkah - Langkah Gaya Mengajar Resiprokal

\begin{tabular}{cll}
\hline Fase & \multicolumn{1}{c}{ Indikator } & \multicolumn{1}{c}{ Tingkah laku guru } \\
\hline 1. & $\begin{array}{l}\text { Menyampaikan tujuan dan } \\
\text { memotivasi siswa }\end{array}$ & $\begin{array}{l}\text { Guru } \\
\text { pembelajaran yang ingin dicapai pada pelajaran } \\
\text { tersebut dan memotivasi siswa }\end{array}$ \\
\hline 2. & Menyampaikan informasi & $\begin{array}{l}\text { Guru menyajikan informasi kepada siswa } \\
\text { dengan jalan demonstrasi lewat bahan bacaan }\end{array}$ \\
\hline & $\begin{array}{l}\text { Mengorganisasikan siswa ke dalam } \\
\text { kelompok }\end{array}$ & $\begin{array}{l}\text { Guru menjelaskan pada siswa bagaimana } \\
\text { caranya membentuk kelompok belajar dan } \\
\text { membantu setiap kelompok agar melakukan } \\
\text { transisi secara efesien. }\end{array}$ \\
\hline 4. & $\begin{array}{l}\text { Membimbing kelompok bekerja } \\
\text { dan belajar }\end{array}$ & $\begin{array}{l}\text { Guru membimbing kelompok - kelompok } \\
\text { belajar pada saat mereka mengerjakan tugas. }\end{array}$ \\
\hline
\end{tabular}

PJKR_ 


\begin{tabular}{cll}
\hline 5. Evaluasi & $\begin{array}{l}\text { Guru mengevaluasi tentang materi yang } \\
\text { dipelajari ( masing }- \text { masing kelompok } \\
\text { mempersentasikan hasil kerjanya) }\end{array}$ \\
\hline 6. Memberi penghargaan & $\begin{array}{l}\text { Guru mancari cara - cara menghargai upaya } \\
\text { atau hasil belajar individu maupun kelompok }\end{array}$ \\
\hline
\end{tabular}

\section{Metode}

Metode penelitian yang digunakan dalam penelitian ini adalah Penelitian Tindakan Kelas. Pendekatan yang digunakan adalah pendekatan kuantitatif yang berguna untuk mengungkapkan kesulitan belajar siswa dalam proses pembelajaran penjas serta cara mengatasi kesulitan - kesulitan tersebut sebagai upaya untuk meningkatkan hasil belajar siswa pada materi tersebut.

Penelitian ini dilaksanakan di SMP Negeri 3 Nipah Panjang Kabupaten Tanjabtim Tahun Ajaran 2015/2016. Penelitian ini akan dilaksanakan pada 5 November sampai dengan 20 Desember 2015. Adapun yang menjadi populasi dalam penelitian ini adalah seluruh siswa kelas VIII A SMP Negeri 3 Nipah Panjang Kab. Tanjabtim Tahun ajaran 2015/2016 yang berjumlah 27 orang. Dengan melibatkan seluruh siswa kelas VIII A SMP Negeri 3 Nipah Panjang Kab. Tanjabtim Tahun ajaran 2015/2016 yang berjumlah 27 orang.

\section{Pembahasan}

\section{Pelaksanaan Siklus I}

Tindakan yang dilakukan adalah menggunakan gaya mengajar resiprokal. Untuk meningkatkan ketuntasan hasil belajar siswa pada siswa kelas VIII A di SMP Negeri 3 Nipah Panjang Kabupaten Tanjabtim Tahun Ajaran 2015/2016. Untuk meningkatkan hasil belajar siswa dan terlibat dalam setiap kegiatan pembelajaran, maka pembelajaran dalam siklus I ini dilakukan tiga kali pertemuan. Berikut ini adalah proses pelaksanaan siklus I yang dimulai dari tahap perencanaan, tindakan, observasi dan refleksi.

a. Perencanaan

Sebelum melakukan perencanaan penelitian terlebih dahulu membuat skenario pembelajaran yang berisikan langkah - langkah kegiatan dalam pembelajaran dengan menggunakan gaya mengajar resiprokal dimana materi yang dibahas hasil belajar lempar lembing. Adapun perencanaan yang akan dibahas yaitu :

- Merancang Rencana Pelaksanaan Pembelajaran ( RPP )

- Mengembangkan materi ajar mengenai lempar lembing.

- Melaksanakan pembelajaran lempar lembing dengan menerapkan gaya mengajar resiprokal dengan uraian kegiatan sebagai berikut:

- Guru mempraktikkan kombinasi teknik dasar lempar lembing dengan dibantu oleh peneliti.

- Siswa memperhatikan kombinasi teknik dasar lempar lembing.

- Guru dan peneliti memperkirakan waktu yang diperlukan untuk mencapai ketuntasan belajar lempar lembing.

PJKR_

http://jurnal.unimed.ac.id/2012/index.php/jpehr/index 
- Siswa melakukan gerakan sesuai materi yang diajarkan guru.

- Bagi siswa yang belum mampu mencapai target belajar, maka diberi kesempatan untuk memperbaiki.

\section{b. Pelaksanaan Tindakan}

Selanjutnya pada kegiatan ini pelaksanaan dilakukan peneliti bersama dengan guru penjas dalam menerapkan pembelajaran lempar lembing menggunakan gaya mengajar resiprokal.

Guna meningkatkan hasil belajar siswa. Pada kegiatan peneliti melakukan pengamatan/ observasi kepada siswa selama pembelajaran berlangsung, sehingga dengan pengamatan terhadap siswa peneliti mampu melakukan pembelajaran dengan baik dan tepat. Pada akhir siklus I yang dilakukan pada pertemuan III untuk melihat hasil belajar yang diperoleh siswa seperti pada tabel deskripsi.

Tabel 3. Deskripsi Hasil Belajar Lempar Lembing ( Siklus I )

\begin{tabular}{clcrl}
\hline No & Hasil Tes & Jumlah Siswa & Persentase & Keterangan \\
\hline 1. & Skor $<70$ & 11 & $40,74 \%$ & Tidak Tuntas \\
\hline 2. & Skor $\leq 70 \leq 100$ & 16 & $59,25 \%$ & Tuntas \\
\hline
\end{tabular}

Berdasarkan tabel deskripsi hasil belajar siklus I diatas dapat dilihat bahwa hasil belajar siswa dalam pembelajaran lempar lembing ternyata telah mulai menigkat. Dari 27 orang siswa yang menjadi subjek dalam penelitian ini, ternyata telah ada 16 orang siswa ( $59,25 \%$ ) yang memiliki ketuntasan belajar, sedangkan 11 orang siswa ( 40,74\% ) masih belum memiliki katuntasan belajar. Nilai rata - rata kelas yang telah diperoleh pada siklus I ini mencapai 64,12.

Dengan memperhatikan tabel di atas dapat dilihat bahwa analisis hasil belajar lempar lembing siswa pada pertemuan III siklus I ternyata hasilnya lebih baik dari tes sebelum siklus walaupun hasilnya belum cukup maksimal, sehingga perlu dilanjutkan ke pelaksanaan siklus II, hal ini dapat dilihat dari kesalahan siswa dalam mempraktekkan pembelajaran lempar lembing dan nilai rata - rata yang diperoleh masih rendah.

Selanjutnya hasil belajar siklus I ini digunakan sebagai acuan dalam memberikan tindakan pada siklus II untuk mengatasi kesulitan siswa dalam mempelajari materi lempar lembing.

Guru melaksanakan kegiatan belajar mengajar tentang teknik dasar lempar lembing, maka dilakukan yaitu :

1) Peneliti menjelaskan unjuk kerja teknik dasar lempar lembing dengan jelas dan sistematis yakni :

a. Guru mengkombinasi teknik dasar lempar lembing.

b. Guru mengajarkan strategi pelaksanaan dengan menggunakan gaya mengajar resiprokal seperti mengatur siswa agar berpasang - pasangan, siswa melakukan teknik lempar lembing secara 
berpasangan. Dan penilai membantu guru dalam menilai hasil belajar lempar lembing dengan memberikan kesempatan tiga kali kemudian mengambil hasil yang terbaik dari setiap tindakan.

2) Guru bertanya kepada siswa tentang materi yang kurang dipahami, kemudian menjelaskannya kembali secara singkat bagian kegiatan yang kurang dipahami oleh siswa.

c. Observasi

Berdasarkan hasil observasi pada siklus I, peneliti kurang memberikan motivasi dan penguatan kepada siswa untuk mendukung terlaksananya pembelajaran dengan baik. Pada pelaksanaan kegiatan, siswa masih mengalami kesulitan dalam melakukan gerakan - gerakan teknik dasar lempar lembing. Siswa masih memerlukan waktu yang lama dalam menguasai satu gerakan saja. Kesulitan siswa tersebut diantaranya siswa tidak mampu melakukan gerakan pelaksanaan dan akhir gerakan dengan baik.

d. Refleksi

Adapun keberhasilan dan kegagalan yang terjadi dalam pelaksanaan tindakan pada siklus I dapat diuraikan sebagai berikut:

1. Peneliti belum mampu secara maksimal dalam mengelola dan melaksanakan kegiatan belajar siswa dan menjelaskan materi lempar lembing. Hal berdasarkan pada data hasil belajar pertemuan III pada siklus I.

2. Guru wajib memberikan motivasi kepada siswa untuk lebih berperan aktif melakukan lempar lembing dengan baik dan benar, seperti cara memegang lembing, sikap awalan dan akhir siswa pada saat melempar lembing dengan tujuan mendapatkan hasil lemparan dengan maksimal.

3. Sebagian besar siswa belum mampu menguasai gerakan dasar lempar lembing.

4. Hasil belajar siswa pada pertemuan III siklus I ini masih rendah, hal ini terlihat dari rata - rata yang diperoleh siswa pada hasil belajar pertemuan III siswa yaitu 64,12.

5. Masih ada sebagian siswa yang kelihatan bingung dan sulit dalam mempraktekkan gerakan dasar lempar lembing.

Untuk memperbaiki kelemahan - kelemahan dan meningkatkan keberhasilan keberhasilan siklus I, maka perlu diadakan siklus II yaitu:

1. Peneliti menyampaikan materi pelajaran lebih jelas dan sistematis agar pemecahan konsep pelajaran yang diajarkan semakin jelas dan tegas.

2. Peneliti meningkatkan penerapan pembelajaran gaya mengajar resiprokal dengan sarana dan prasarana yang lebih baik lagi.

PJKR_

http://jurnal.unimed.ac.id/2012/index.php/jpehr/index 
3. Peneliti mengarahkan siswa agar lebih teliti dalam melakukan gerakan dasar lempar lembing sehingga tidak terjadi kesalahan yang sama dengan siklus I.

\section{Pelaksanaan Siklus II}

Tindakan yang dilakukan adalah menerapkan gaya mengajar resiprokal. Untuk meningkatkan ketuntasan hasil belajar siswa pada siswa kelas VIII A di SMP Negeri 3 Nipah Panjang Kabupaten Tanjabtim Tahun Ajaran 2015/2016. Untuk meningkatkan siswa dan terlibat dalam setiap kegiatan pembelajaran, maka pembelajaran dalam siklus II ini dilakukan tiga kali pertemuan. Berikut ini adalah proses pelaksanaan siklus II yang dimulai dari tahap perencanaan, tindakan, observasi dan refleksi.

\section{a. Perencanaan}

Pada tahap ini peneliti membuat alternatif pemecahan masalah untuk menguasai kesulitan siswa dalam pembelajaran lempar lembing, terutama tentang teknik dasar gerakan lempar lembing. yang diberikan pada siklus I sehingga pemahaman siswa tentang teknik dasar lempar lembing semakin jelas. Perencanaan ini khususnya dilakukan pada siswa yang masih memperoleh nilai rendah, dan meminta siswa yang memiliki nilai rendah untuk mengulang gerakan lempar lembing.

b. Pelaksanaan Tindakan

Selanjutnya pada kegiatan ini pelaksanaan dilakukan peneliti bersama dengan guru penjas dalam menerapkan gaya mengajar resiprokal pada materi pembelajaran lempar lembing. Guna meningkatkan hasil belajar siswa. Pada kegiatan peneliti melakukan pengamatan/observasi kepada siswa selama pembelajaran berlangsung, sehingga dengan pengamatan terhadap siswa peneliti mampu melakukan pembelajaran dengan baik dan tepat. Pada akhir siklus II yang dilakukan pada pertemuan III untuk melihat hasil belajar yang diperoleh siswa seperti pada tabel deskripsi.

Tabel 4. Deskripsi Hasil Belajar Lempar lembing (Siklus II)

\begin{tabular}{clccl}
\hline No & Hasil Tes & Jumlah Siswa & Persentase & Keterangan \\
\hline 1. & Skor $<70$ & 4 & $14,81 \%$ & Tidak Tuntas \\
\hline 2. & Skor $\leq 70 \leq 100$ & 23 & $85,18 \%$ & Tuntas
\end{tabular}

Berdasarkan tabel deskripsi hasil belajar siklus II diatas dapat dilihat bahwa hasil belajar siswa dalam pembelajaran lempar lembing ternyata telah mulai menigkat. Dari 27 orang siswa yang menjadi subjek dalam penelitian ini, ternyata telah ada 23 orang siswa ( $85,18 \%$ ) yang memiliki ketuntasan belajar, sedangkan 4 orang siswa ( $14,81 \%)$ masih belum memiliki katuntasan belajar. Nilai rata - rata kelas yang telah diperoleh pada siklus II ini mencapai 86,80. 
Dengan memperhatikan tabel di atas dapat dilihat bahwa analisis hasil belajar lempar lembing siswa pada pertemuan III siklus II ternyata hasilnya lebih baik dari pertemuan III siklus I, dan peningkatan ketuntasan belajar siswa telah cukup signifikan namun guru penjas harus tetap memberikan bimbingan selanjutnya.

Selanjutnya hasil belajar siklus II ini digunakan sebagai acuan dalam memberikan pembelajaran dengan menerapkan gaya mengajar resiprokal bagi guru penjas di SMP Negeri 3 Nipah Panjang Kabupaten Tanjung Jabung Timur .

c. Observasi

Berdasarkan hasil observasi pada siklus I, peneliti masih perlu memberikan motivasi dan penguatan kepada siswa untuk mendukung terlaksanaanya pembelajaran dengan baik. Pada pelaksanaan kegiatan, siswa telah memahami gerakan lempar lembing dan telah mengetahui cara memperbaiki kesalahan gerakan yang mereka lakukan.

d. Refleksi

Adapun keberhasilan dan kegagalan yang terjadi dalam pelaksanaan tindakan siklus II ini dapat diuraikan sebagai beikut:

1. Peneliti belum mampu secara maksimal dalam mengelola dan melaksanakan kegiatan belajar siswa dan menjelaskan materi lempar lembing.

2. Sebagian besar siswa sudah mampu menguasai gerakan dasar lempar lembing dengan baik. Berikut ini dapat dilihat nilai rata - rata hasil belajar siswa dari mulai sebelum siklus, siklus I dan siklus II.

Tabel 5. Nilai rata - rata Sebelum siklus, Siklus I dan Siklus II

\begin{tabular}{clcl}
\hline No & Hasil Tes & Persentase Nilai Rata - Rata & Keterangan \\
\hline 1. & Sebelum Siklus & 40,50 & Tidak Tuntas \\
\hline 2. & Siklus I & 64,12 & Tidak Tuntas \\
\hline 3. & Siklus II & 86,80 & Tuntas \\
\hline
\end{tabular}

Ketuntasan belajar menggunakan pendekatan kelompok dan lebih menekankan individualis. Namun dalam kenyataannya, bakat dan hasil belajar siswa itu berbeda - beda. Belum tentu siswa yang satu sebaik siswa yang lain dalam penguasaan materi. Hal inilah yang perlu dicermati oleh guru. Guru harus bisa memahami setiap perbedaan siswanya. Guru tidak boleh mengambil sampel tertinggi maupun terendah. Melalui penerapan gaya mengajar resiprokal yang telah diterapkan pada siswa kelas VIII A SMP Negeri 3 Nipah Panjang Kabupaten Tanjabtim ternyata dapat meningkatkan ketuntasan belajar siswa secara signifikan.

Berdasarkan hasil persentase siswa yang telah tuntas hasil belajar lempar lembing dengan menggunakan gaya mengajar resiprokal secara klasik dari tes 
pada siklus I ( $64,12 \%$ ) maka persentase yang didapat dari siklus II ( $86,80 \%$ ) ini sudah terjadi peningkatan.

Dengan demikian dapatlah dikatakan gaya mengajar resiprokal yang dilakukan oleh guru berakhir pada siklus II dengan hasil belajar lempar lembing yang tadinya rendah menjadi meningkat. Peningkatan pengelolaan pembelajaran dengan gaya mengajar resiprokal lebih efektif dan tepat sehingga didapatlah ketuntasan hasil belajar.

\section{Simpulan}

Berdasarkan hasil pembahasan penelitian dapat ditarik kesimpulan bahwasanya ada peningkatan hasil belajar lempar lembing dengan munggunakan gaya mengajar resiprokal pada siswa kelas VIII A SMP Negeri 3 Nipah Panjang Kabupaten Tanjabtim Tahun Ajaran 2015/2016.

\section{Rujukan}

Adi, Winendra, 2008. Seni Olahraga Atletik. Yogyakarta: Pustaka Insan Madani

Arikunto, Suharsimi, 2002. Prosedur Penelitian (Suatu Pendekatan Praktek) Jakarta: Edisi Revisi V

Arikunto.S, dkk, 2006. Penelitian Tindakan Kelas. Jakarta: PT Bumi Aksara

Brotosuryo, dkk, 1992. Perencanaan Pengajaran Pendidikan Jasmani dan Kesehatan. Jakarta: Depdikbud Proyek Peningkatan Mutu Guru SD Setara D-II dan Pendidikan Kependudukan Bagian Proyek Penataran Guru Pendidikan Jasmani dan Kesehatan SD Setara D-II

Husdarta dan Syahputra Y.M, 2000. Belajar Pembelajaran. Jakarta: Departemen Pendidikan Nasional Dektoriat Jendral Pendidikan Dasar Dan Menengah Bagian Proyek Penataran Setara D-III

Jarver, Jess, 2009. Belajar dan Berlatih Atletik. Bandung: Pionir Jaya

Kristiyanto, Agus, 2010. Penelitian Tindakan Kelas (PTK). Jawa Tengah: UPT Penerbitan dan Pencetakan UNS

Kurniawan, Feri, 2011. Buku Pintar Olahraga. Jakarta: Laskar Graha

Mosston, Muska, 1999. Teaching Physical Education, Diterjemahkan Oleh Sudjarwo dan Furqon, Surakarta: Program Pascasarjana Universitas Sebelas Maret

Muklis, 2007. Olahraga Kegemaranku Atletik. Klaten: PT. Intan Pariwara

Nurkancana, W, 1986. Evaluasi Pendidikan. Surabaya: Usaha Nasional

Propayanda, D. Rahmad, 2014. Upaya Meningkatkan Hasil Belajar Lompat Tinggi Gaya Stradlle Melalui Model Pembelajaran Bermain Pada Siswa Kelas XII IPA 6 SMA Negeri 1 Kota Jambi Tahun Ajaran 2014/2015. Jambi: Universitas Jambi.

Rahayu, T. Ega, 2013. Strategi Pembelajaran Pendidikan Jasmani. Bandung: Cv. Alfa Beta

Ridwan, Iwan, dkk, 2008. Atletik. Surakarta: PT. Widya Duta Grafika

Samsudin, 2008. Pembelajaran Pendidikan Jasmani Olahraga dan Kesehatan. Jakarta: Litera Prenada Media Group

PJKR_

http://jurnal.unimed.ac.id/2012/index.php/jpehr/index 
Sudjana, 2002. Metode Statistika. Bandung: Tarsito

Sudjana, 2005. Metode Statistika. Bandung: Tarsito

Supandi, 1992. Strategi Belajar Mengajar Penjas. Jakarta: Depdikbud

Suryosubroto B.1997. Proses Belajar Mengajar di Sekolah. Jakarta.Rineka Cipta

Wiarto, Giri. 2013. Atletik. Yogyakarta: Graha Ilmu 